\title{
EBV-positive Diffuse Large B-cell Lymphoma, NOS, in a Filipino Patient: Mimickers and Essential Ancillary Studies
}

\author{
Katreena Sasis, ${ }^{1}$ Daphne Lee, ${ }^{2}$ Alejandro Arevalo, ${ }_{1}^{1}$ Beatrice Tiangco, ${ }^{2}$ Rose Lou Marie Agbay ${ }^{1}$ \\ ${ }^{1}$ Department of Laboratory Medicine and Pathology, The Medical City, Pasig City, Philippines \\ ${ }^{2}$ Section of Medical Oncology, Department of Medicine, The Medical City, Pasig City, Philippines
}

\section{ABSTRACT}

Epstein-Barr virus positive diffuse large B-cell lymphoma (EBV+ DLBCL) is prevalent among Asians but is underreported in the Philippine setting. We report the case of an 88-year-old male who presented with difficulty swallowing. CT scan showed an ill-defined soft tissue focus with calcifications in the supraglottic to hypopharyngeal region measuring approximately $2.6 \times 1.7 \times 1.5 \mathrm{~cm}$, and multiple lymphadenopathies in the head and neck. Biopsy of the masses at the left tonsil, left arytenoid mucosa, pyriform sinus, and aryepiglottic fold showed large lymphoid cells with several Reed-Sternberg-like cells in a background of small lymphocytes, neutrophils, few eosinophils and histiocytes. A panel of immunohistochemical stains and EBER-ish were performed to differentiate among six entities that were morphologically similar to the patient's case, namely, classic Hodgkin lymphoma, T-cell/histiocyte-rich large B-cell lymphoma (THRLBCL), DLBCL, NOS, anaplastic variant, B-cell lymphoma, unclassifiable, with features intermediate between DLBCL and classic HL (gray zone lymphoma), and infectious mononucleosis (IM). The neoplastic cells expressed CD20, CD30, CD45, PAX5, CD10, MUM-1, BCL6, BCL2, and C-myc, while CD3, CD15 and ALK-1 were negative. The cells of interest also showed nuclear staining (30-40\%) on Epstein-Barr virus encoding RNA in-situ hybridization (EBER-ish). The Ki-67 showed a proliferation index of $40-50 \%$. Given the differences in prognosis and treatment among these diseases, judicious use of immunostains and EBER-ish is recommended for accurate diagnosis.

Key words: Immunohistochemistry, Philippines, DLBCL, Epstein-Barr virus, EBV+ DLBCL

ISSN 2507-8364 (Online)

Printed in the Philippines. Copyright $\odot 2021$ by the PJP.

Received: 23 September 2021.

Accepted: 9 November 2021.

Published online first: 24 November 2021.

https://doi.org/10.21141/PJP.2021.15

Corresponding author: Katreena C. Sasis, MD E-mail:treena.sasis@outlook.com

ORCiD: https://orcid.org/0000-0001-9483-4150

\section{INTRODUCTION}

Diffuse large B-cell lymphoma, of no special type (DLBCL, NOS) is a neoplasm composed of diffusely growing B lymphocytes with nuclei twice as large as that of normal lymphocytes. Histomorphology and immunohistochemical studies have allowed sub-classifications of DLBCL, aiding in both diagnosis and treatment. ${ }^{1}$ EpsteinBarr virus positive DLBCL, NOS (EBV+ DLBCL) is one such classification which accounts for $5-15 \%$ of DLBCL patients among Asians. ${ }^{2}$ From the time that it was initially described by Oyama et al in 2003, there have been multiple studies on its prevalence across Asia. ${ }^{3}$ EBV + DLBCL is further classified into two subtypes: a polymorphic subtype with surrounding reactive infiltrates, and a monomorphic subtype composed of sheets of large cells. These subtypes are important to note because of their close resemblance to other lymphoproliferative neoplasms. ${ }^{1}$

Despite the increased prevalence of $\mathrm{EBV}+$ DLBCL in Asian countries, this entity remains underreported in the Philippine setting. An exhaustive search on Philippine e-journals, HERDIN Plus, and the Philippine Journal of Pathology yielded no reports of EBV + DLBCL. This report aims to add to the body of knowledge on this disease in the local setting, and elucidate a method to differentiate among six morphologically similar entities.

\section{CASE}

This is a case of an 88-year-old Filipino, previously healthy male who presented with rapidly worsening 
difficulty of swallowing solid food, which started two weeks prior to consultation. This symptom was associated with gradual weight loss of approximately $10 \mathrm{~kg}$. There was no fever, night sweats, chest pain, or difficulty of breathing. Complete blood count showed the following result: hemoglobin of $80 \mathrm{~g} / \mathrm{L}$, hematocrit of 0.25 , white blood cell count of $8.50 \times 10^{9} / \mathrm{L}$, and platelet count of $287 \times 10^{9} / \mathrm{L}$. Differential count was predominantly neutrophilic with no immature cells seen. Serum lactate dehydrogenase (LDH) was normal. Serum EBV level was not tested. CT scan showed an ill-defined soft tissue focus with calcifications in the supraglottic to hypopharyngeal

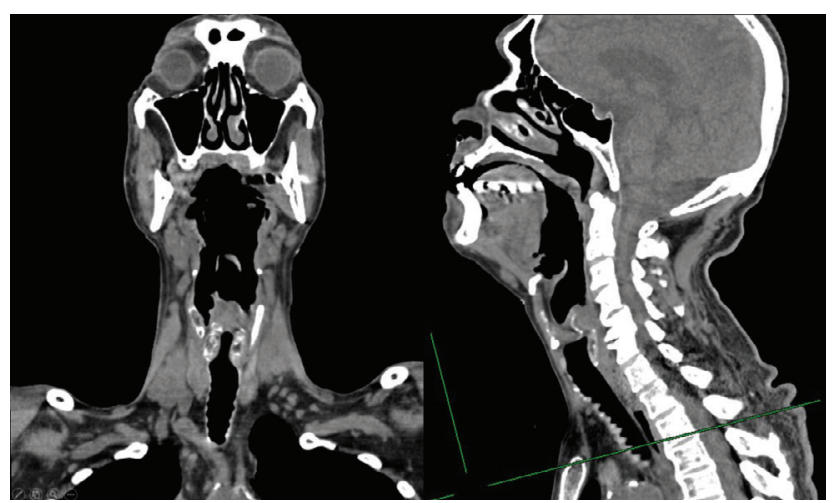

Figure 1. CT scan showing an ill-defined soft tissue focus along with enlarged, prominent cervical lymph nodes. region measuring approximately $2.6 \times 1.7 \times 1.5 \mathrm{~cm}$, and prominent, enlarged, round to ovoid lymph nodes at the submental, left submandibular, right mid-jugulocarotid and left upper to lower jugulocarotid and posterior cervical spaces (Figure 1). An F-18 FDG PET scan done a month later revealed multiple FDG-avid (Lugano Score 5) lymphadenopathies scattered in the bilateral cervical, right axillary, mediastinal, right peribronchial, right subpleural, peritoneal, omental, mesenteric, retroperitoneal, pelvic and inguinal regions, with the largest lymphadenopathy measuring $3.2 \times 2.8 \mathrm{~cm}$ in greatest dimensions (Figure 2). Laryngoscopy showed masses at the left tonsil, left arytenoid mucosa, pyriform sinus, and aryepiglottic fold which were submitted for histopathologic evaluation.

Microscopic examination showed proliferation of large lymphoid cells with several Reed-Sternberg-like cells in a background of small lymphocytes, neutrophils, few eosinophils and histiocytes. (Figure 3). Using formalin-fixed, paraffin-embedded tissue sections, immunohistochemical studies were performed on automated staining platforms according to the manufacturer's instructions. The antibodies used, their dilutions, and respective vendors were as follows: anti-CD3 (clone 2GV6; Ventana/Roche Tissue Diagnostics, Tucson, AZ, USA; 1:100); anti-CD10 (clone SP67; Ventana/Roche Tissue Diagnostics, Tucson, AZ, USA; 1:100); anti-CD15 (clone MMA; Ventana/Roche Tissue Diagnostics, Tucson, AZ, USA; 1:100); anti-CD20 (clone L26; Ventana/Roche Tissue Diagnostics, Tucson,

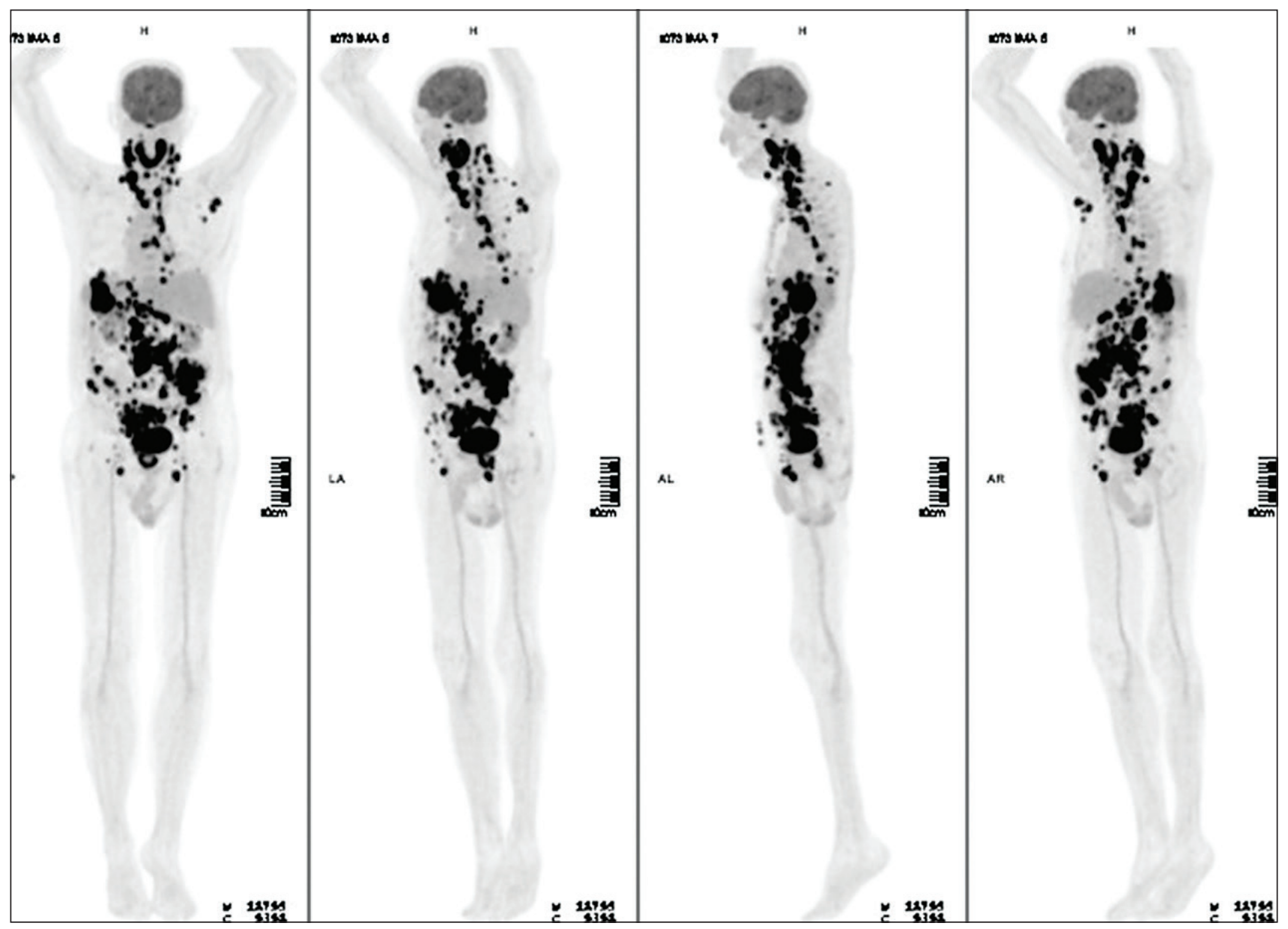

Figure 2. F-18 FDG PET scan showing multiple FDG-avid (Lugano Score 5) lymphadenopathies. 


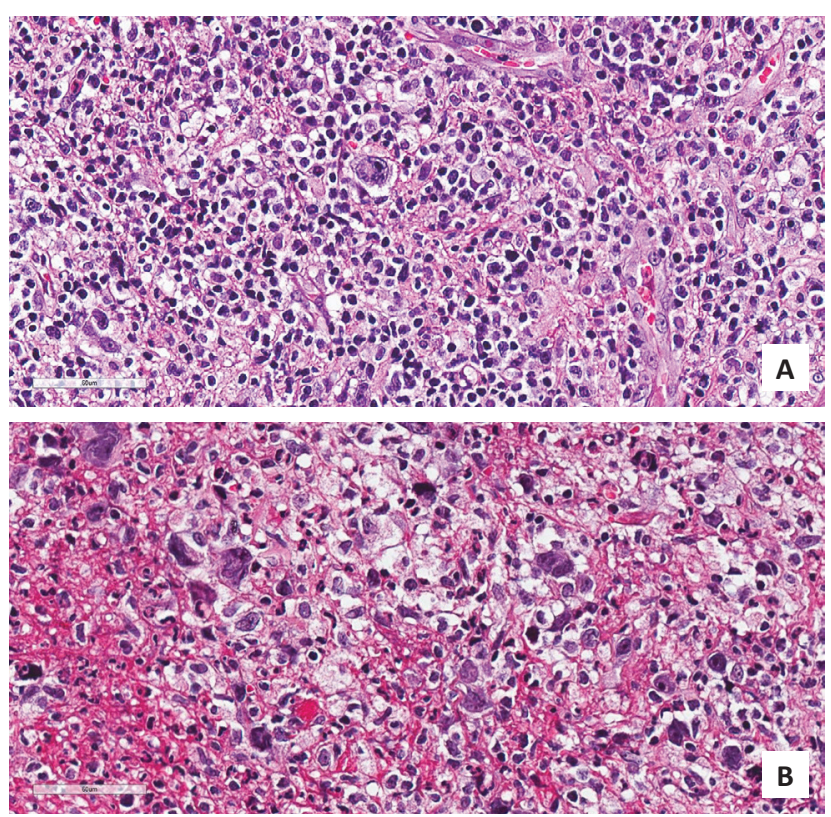

Figure 3. (A and B) The tumor is composed of sheets of large lymphoid cells surrounded by small lymphocytes, neutrophils, few eosinophils and histiocytes. There are also many scattered Reed-Sternberg-like cells showing irregularly shaped nuclei, prominent nucleoli, and scant basophilic cytoplasm (H\&E, 40x).
AZ, USA; 1:100); anti-CD30 (clone Ber-H2; Ventana/Roche Tissue Diagnostics, Tucson, AZ, USA; 1:100); anti-CD45 (clone RP2/18; Ventana/Roche Tissue Diagnostics, Tucson, AZ, USA; 1:100); anti-PAX5 (clone SP34; Ventana/Roche Tissue Diagnostics, Tucson, AZ, USA; 1:100); anti-MUM-1 (clone MRQ-43; Ventana/Roche Tissue Diagnostics, Tucson, AZ, USA; 1:100); anti-BCL6 (clone GI191E/A8; Ventana/ Roche Tissue Diagnostics, Tucson, AZ, USA; 1:100); antiBCL2 (clone 124; Ventana/Roche Tissue Diagnostics, Tucson, AZ, USA; 1:100); anti-c-myc (clone 9E10; Ventana/ Roche Tissue Diagnostics, Tucson, AZ, USA; 1:100); antiALK-1 (clone ALK01; Ventana/Roche Tissue Diagnostics, Tucson, AZ, USA; 1:100); and anti-Ki-67 (clone 30-9; Ventana/Roche Tissue Diagnostics, Tucson, AZ, USA; 1:100). Epstein-Barr encoding region in-situ hybridization (EBER-ish) was performed using EBER probe (Leica BONDMAX, Leica Biosystems, Buffalo Grove, IL, USA), using the built-in protocol from the manufacturer.

The large lymphoid cells as well as the Reed-Sternberg-like cells expressed CD45, CD20, PAX5, CD30 (30\%), CD10 (60\%), BCL6 (30\%), MUM-1 (80\%), BCL2 (20\%), and c-myc (10\%), while CD3, CD15 and ALK-1 were negative. The cells of interest also showed nuclear staining (30-40\%) on Epstein-Barr encoding region in-situ hybridization (EBER-ish). The Ki-67 showed a proliferation index of $40-50 \%$ (Figure 4). Based on the morphology and the

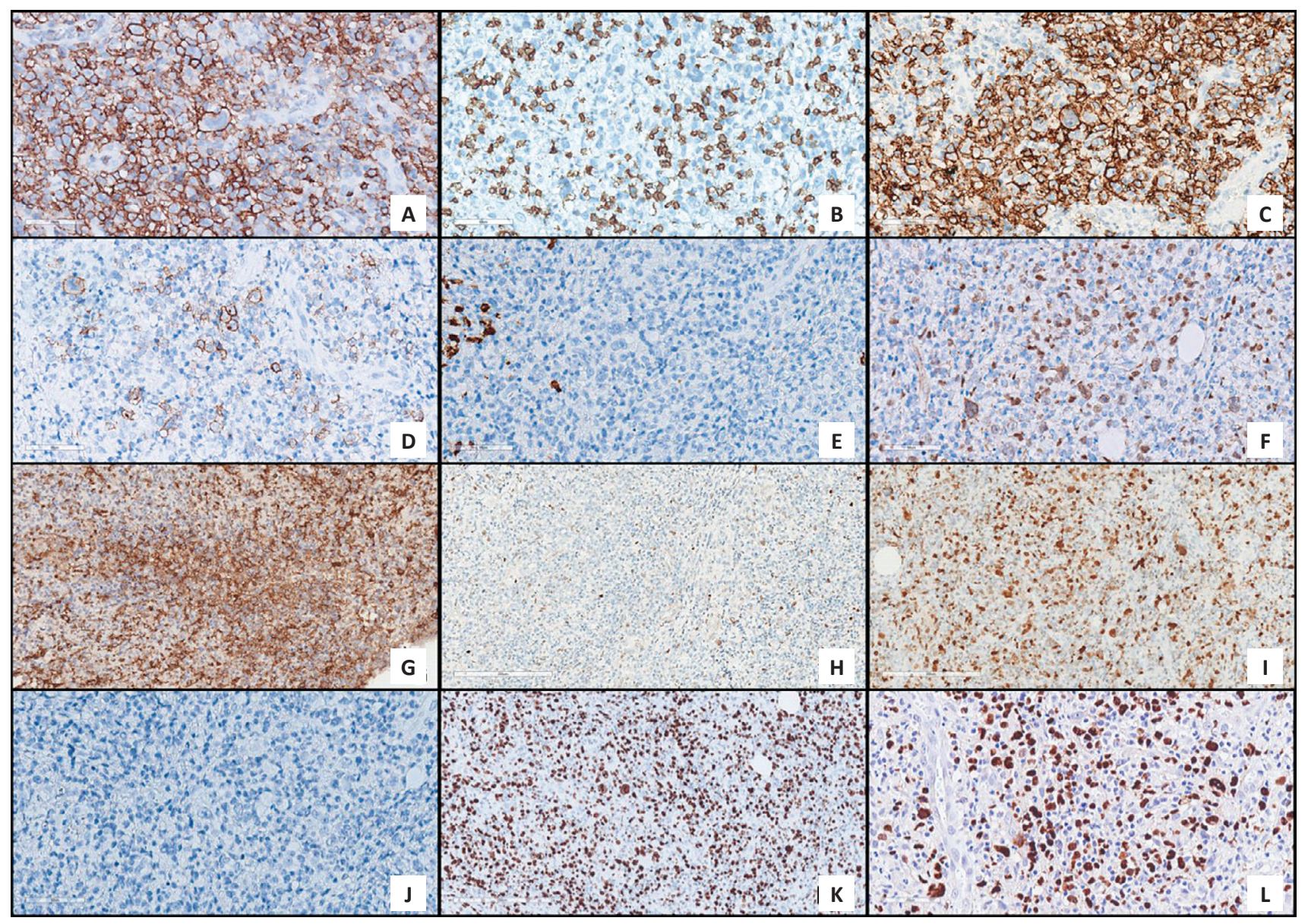

Figure 4. The large cells and Reed-Sternberg-like (RS-like) cells were positive for LCA (A), CD20 (C), and PAX5 (F) (40x). Some of the large cells and RS-like were positive for CD30 (30\%) (D). The tumor cells also expressed CD10 (30\%) (G), BCL6 (30\%) (H) and MUM-1 (80\%) (I) (20x). The immunostains for CD3 (B), CD15 (E), and ALK-1 (J) were negative (40x). Ki-67 shows a high (40-50\%) proliferation index (K) (20x). Approximately $30-40 \%$ of the large cells showed nuclear staining on Epstein-Barr encoding region in-situ hybridization (L) (20x). 
immunoprofile, this case was thus signed out as an EBV+ DLBCL, NOS.

\section{DISCUSSION}

EBV is one of the first oncogenic viruses to be identified. It is oncogenic partly due to its link with immunosuppression and chronic antigenic activation. Worldwide, EBV infection has a prevalence ranging between 80-95\%. It is more commonly associated with nasopharyngeal carcinoma and Burkitt lymphoma, though it is not rarely linked with various other tumors. ${ }^{4}$

$\mathrm{EBV}+\mathrm{DLBCL}$ has a higher prevalence in Asia than in Europe and America (Table 1)..$^{5-11}$ In the Philippines, there have been published studies documenting lymphomas in general, but no recent literature focusing on DLBCL, EBV positive or otherwise. A 2004 study of various cases of lymphoma at a tertiary hospital showed a greater prevalence of non-Hodgkin lymphoma (NHL) as compared to Hodgkin lymphoma (HL), involving a median age of 29 years and most often involving the neck. Most of the cases were Stage IIA on diagnosis. ${ }^{12}$ One study done more than a decade ago reported few cases of $\mathrm{EBV}+\mathrm{HL}$, but not EBV + DLBCL. ${ }^{13}$ It is postulated that genetic factors (e.g., HLA types) and EBV strains play a role in the regional differences in EBV prevalence. ${ }^{4}$

Various studies across many populations report the median age of DLBCL to be 70 years, with higher incidence in males and in developing countries. A similar trend is observed with EBV + DLBCL. ${ }^{2}$ There have been reports of this entity appearing over a wide range of ages, though it is less common and carries a better prognosis among younger patients; thus, the "elderly" designation in EBV+ DLBCL was removed in the 2017 edition of the WHO classification guidelines., ${ }^{2,14-16}$ Immunosenescence, which comes with aging, might explain the higher prevalence of EBV+ DLBCL and related diseases among the elderly. It involves dysregulation of the T-cell response, loss of immunosurveillance, deficiencies in cytokine production, and anergic memory cells. ${ }^{4}$

Majority of EBV + DLBCL patients present with extranodal masses (particularly in the tonsils, skin, lungs, and gastrointestinal tract) and lymphadenopathy. Around $60 \%$ of patients present with B symptoms, such as fever, night sweats, and weight loss. ${ }^{2,17} \mathrm{LDH}$ levels are often increased. ${ }^{2}$ $\mathrm{EBV}+$ DLBCL predominantly presents with a mixed proliferation of large transformed cells, immunoblasts and Reed-Sternberg-like cells, in a background of plasma cells, plasmablasts, histiocytes, epithelioid cells and small lymphocytes. This polymorphic pattern, as is seen in this case, can resemble T-cell/histiocyte-rich large B-cell lymphoma (THRLBCL) or classic HL. Geographical areas of necrosis or angioinvasion may or may not be present. A monomorphic subtype has also been described, composed of sheets of large cells, which may be difficult to differentiate from EBV negative DLBCL without immunohistochemical studies. ${ }^{2,18}$

The similarity of morphologic features between EBV+ DLBCL and other lymphomas presents a diagnostic difficulty. Other considerations based on morphology and clinical presentation included T-cell/histiocyte-rich large B-cell lymphoma (THRLBCL), DLBCL, NOS, anaplastic variant, and B-cell lymphoma, unclassifiable, with features intermediate between DLBCL and classic HL (gray zone lymphoma). A benign entity, infectious mononucleosis (IM), was also considered. Various immunohistochemical studies were employed to identify the type of tumor from among its morphologically similar counterparts. A comparison of the immunoprofile of this case and the differential diagnoses is presented in Table 2.

On the initial panel, a B-cell origin was considered due to strong expression of CD20 in the large cells and RS-like cells, and negative CD3. The Ki-67 indicated a moderate to high proliferation index. Among the known B-cell lymphomas, these five entities were selected as differential diagnoses due to the common feature of large B cells and occasional RS-like cells, surrounded by different types of reactive cells, with moderate to high proliferation index. Four of these entities are also more prevalent among elderly males as in this case. Clinically, these entities present with nodal or extranodal masses, with or without lymphadenopathies, with gray zone lymphoma being the exception.

Morphologically, one of the leading considerations was classic Hodgkin lymphoma, particularly the mixed cellularity subtype. This is the most common subtype in developing countries. It is noted that mixed cellularity cHL resembles the polymorphic subtype of EBV + DLBCL. The strong positivity of PAX-5, and CD45 in this case, however, made this diagnosis less likely. In addition, cHL usually has a slower progression and is often nodal in presentation. THRLBCL is characterized by large B cells, surrounded by small T-cells and histiocytes. However, it is defined as having neoplastic cells occupying $<10 \%$ of the cell population. EBER-ish is also mostly negative in
Table 1. Prevalence of EBV+ DLBCL among different countries

\begin{tabular}{|c|c|c|c|c|}
\hline Country & Age groups studied & Sample & \% prevalence & EBER cut-off \\
\hline Japan $^{5}$ & $55-84$ & $18 / 260$ & $6.9 \%$ & $30 \%$ \\
\hline \multirow[t]{4}{*}{ China $^{6}$} & Elderly $>50$ & $25 / 141$ & $18 \%$ & $20 \%$ \\
\hline & $<50$ & $10 / 74$ & $14 \%$ & $20 \%$ \\
\hline & Elderly $>50$ & $19 / 147$ & $13 \%$ & $50 \%$ \\
\hline & $<50$ & $7 / 77$ & $9 \%$ & $50 \%$ \\
\hline \multirow[t]{2}{*}{ Korea $^{7}$} & Elderly $>50$ & $35 / 376$ & $9.3 \%$ & $20 \%$ \\
\hline & $<50$ & $13 / 195$ & $6.7 \%$ & $20 \%$ \\
\hline Germany ${ }^{8}$ & Elderly $>50$ & $4 / 169$ & $2 \%$ & "majority" \\
\hline Switzerland, Italy, Austria ${ }^{9}$ & Elderly $>50$ & $8 / 258$ & $3.1 \%$ & $10-100 \%$ \\
\hline Mexico $^{8}$ & Elderly $>50$ & $9 / 136$ & $7 \%$ & "majority" \\
\hline United States ${ }^{10}$ & Elderly $>60$ & $5 / 95$ & $5.3 \%$ & None; at least $80 \%$ of cells in tumors considered positive \\
\hline
\end{tabular}




\begin{tabular}{|c|c|c|c|c|c|c|c|}
\hline IHCs & Patient & Classic Hodgkin Lymphoma & $\begin{array}{l}\text { T-cell/histiocyte-rich } \\
\text { large B cell }\end{array}$ & $\begin{array}{c}\text { B-cell lymphoma, } \\
\text { unclassifiable, with features } \\
\text { intermediate between } \\
\text { DLBCL and classic HL }\end{array}$ & $\begin{array}{l}\mathrm{EBV}+\mathrm{DLBCL} \\
\text { NOS }\end{array}$ & DLBCL, NOS & $\begin{array}{c}\text { Infectious } \\
\text { mononucleosis }\end{array}$ \\
\hline CD3 & Negative & $\begin{array}{l}\text { Negative, but }(+) \text { in } \\
10 \% \text { of cases }\end{array}$ & $\begin{array}{c}\text { Negative in large } \\
\text { neoplastic cells; }(+) \text { in } \\
\text { T cells in background }\end{array}$ & $\begin{array}{l}\text { Negative in large cells; } \\
(+) \text { in T cells in background }\end{array}$ & Negative & Negative & $\begin{array}{l}(+) \text { in surrounding } \\
\text { small cells }\end{array}$ \\
\hline $\mathrm{CD} 20$ & $(+)$ & $\begin{array}{c}\text { Variably positive and } \\
\text { weak in } 20-40 \% \text { of cases }\end{array}$ & $\begin{array}{c}(+) \text { in large } \\
\text { neoplastic cells }\end{array}$ & $\begin{array}{l}(+) \text { strong in cases } \\
\text { that resemble } \mathrm{cHL} \\
(-) \text { in cases that } \\
\text { resemble DLBCL }\end{array}$ & $(+)$ & $\begin{array}{l}(+) \text {; can be dim if } \\
\text { with plasmacytoid } \\
\text { differentiation }\end{array}$ & $\begin{array}{c}(+) \text { in } \\
\text { immunoblasts } \\
\text { and germinal } \\
\text { center B-cells }\end{array}$ \\
\hline Ki-67 & $40-50 \%$ & High & High & High & High & $40-90 \%$ & Moderate to high \\
\hline PAX-5 & $(+)$ strong & $\begin{array}{l}\text { Weakly positive; negative } \\
\text { in } 10 \% \text { of cases } \\
\text { Stronger in nodular } \\
\text { lymphocyte-predominant } \mathrm{HL}\end{array}$ & $\begin{array}{l}(+) \text { strong in large } \\
\text { neoplastic cells }\end{array}$ & (+) strong & (+) strong & (+) strong & $\begin{array}{c}(+) \text { in } \\
\text { immunoblasts }\end{array}$ \\
\hline CD15 & Negative & $\begin{array}{c}(+) \text {; Negative in } 15-25 \% \text {, } \\
\text { usually in nodular } \\
\text { lymphocyte-predominant }\end{array}$ & Negative & $\begin{array}{c}(+) \text { in cases that } \\
\text { resemble } \mathrm{DLBCL} \\
(-) \text { in cases that resemble } \mathrm{cHL}\end{array}$ & Negative & Negative & Negative \\
\hline ALK-1 & Negative & Negative & Negative & Negative & Negative & Negative & Negative \\
\hline CD30 & $(+) 30 \%$ & $(+)$ & Negative & $(+)$ & $\begin{array}{l}(+/-), \text { usually } \\
\text { weak and } \\
\text { partial }\end{array}$ & $\begin{array}{l}(+) \text { only } 10-20 \% \\
\text { and anaplastic }\end{array}$ & $\begin{array}{c}(+) \text { in } \\
\text { immunoblasts }\end{array}$ \\
\hline CD10 & $(+) 30 \%$ & Negative & $(+)$ & Negative & Negative & $(+)$ in $30-50 \%$ & Negative \\
\hline BCL6 & $(+) 30 \%$ & $(+)$ & $(+)$ & $(+)$ Variable & Negative & $(+)$ in $60-90 \%$ & Negative \\
\hline $\mathrm{BCL2}$ & $(+) 20 \%$ & $(+)$ & $(+)$ variable & $(+)$ Variable & $(+)$ Infrequent & $\begin{array}{l}(+) \text { Variable [criteria: } \\
50 \% \text { or more of cells] }\end{array}$ & Negative \\
\hline c-myc & $(+) 10 \%$ & $(+)$ variable & (+) variable & (+) Variable & (+) Infrequent & $\begin{array}{l}(+) \text { Variable [criteria: } \\
40 \% \text { or more of cells] }\end{array}$ & No data \\
\hline EBER-ish & (+) $30-40 \%$ & $\begin{array}{l}\text { often positive in mixed- } \\
\text { cellular and lymphocyte } \\
\text { depleted ( } 75 \% \text { of cases) }\end{array}$ & Rarely positive & Negative (positive in 15\%) & $\begin{array}{l}\text { (+); arbitrary } \\
\text { cutoff of } 20- \\
40 \% \text { of cells. }\end{array}$ & Negative & $(+)$ \\
\hline CD45 & $(+)$ & $\begin{array}{c}\text { Negative } \\
(+) \text { in nodular lymphocyte- } \\
\text { predominant }\end{array}$ & $\begin{array}{c}(+) \text { in large } \\
\text { neoplastic cells }\end{array}$ & $(+)$, focally & Negative & (+) Variable & $\begin{array}{c}(+) \text { in } \\
\text { immunoblasts }\end{array}$ \\
\hline MUM-1 & $(+) 80 \%$ & $(+)$ & $(+)$ & $(+)$ & $(+)$ & $\begin{array}{c}(+) \text { in } 35-65 \% \text { of cases } \\
\text { if with plasmacytoid } \\
\text { differentiation }\end{array}$ & $(+)$ \\
\hline
\end{tabular}

this entity. Gray zone lymphoma has variable histologic features; the main criteria is that the immunohistochemical profiles are not consistent with what is expected from the morphology. There is a morphologic and immunoprofile overlap between cHL and DLBCL. In this case, the morphology suggests cHL, but immunohistochemical profile most closely matches DLBCL, NOS, which makes gray zone lymphoma a possible diagnosis. However, this disease mostly presents in young to middle aged patients, and often occurs in the mediastinum. EBER-ish is also frequently negative in gray zone lymphoma. It is known that EBV+ DLBCL is usually of non-germinal center $\mathrm{B}$-cell origin, however, in a study done by Lu et al., at least $11.5 \%$ of EBV + DLBCL cases were CD10 positive. ${ }^{6}$

A similar dilemma was discussed in a case report by Wang and colleagues, describing a tumor that was histologically similar to DLBCL, classic HL, and gray zone lymphoma. The study used other techniques not readily available in the Philippine setting, such as OCT2 and BOB1 immunostains; however, a definite diagnosis was still not established. It was proposed that EBV is associated with lymphomas that may not fit neatly into WHO classifications or IHC-driven categorizations. ${ }^{19}$

A non-neoplastic differential, though no less important, is infectious mononucleosis (IM). While it is observed more often in younger patients, it can present in older age and be mistaken for malignancy. IM presents clinically with fever, pharyngitis, and cervical to generalized lymphadenopathy in $50 \%$ of patients. Immunoblasts are increased, sometimes forming sheets, which can stain positive for CD30 and CD45, like in this patient. There can also be large, monoto multinucleated cells with prominent nucleoli, which can be mistaken for Reed-Sternberg or Hodgkin cells. However, in IM, there is relatively preserved follicular architecture, and the background is polymorphous and composed mostly of small T-lymphocytes (CD3+ and $\mathrm{CD} 8+) .{ }^{20}$ BCL2 and BCL6 are also negative in IM. ${ }^{21}$

Ancillary studies to differentiate reactive from neoplastic hematolymphoid entities include flow cytometry to determine the clonality of populations through light chain restriction, morphologic assessment of light chain Kappa/ Lambda mRNA ratio with CISH, and/or detection of gene rearrangements in BCL2, BCL6 and MYC with FISH. ${ }^{21,22}$

A clonal IGH and/or IGK gene rearrangement by Southern blot, polymerase chain reaction, or nextgeneration sequencing will also support the diagnosis of a B-cell neoplasm. However, molecular methods are only necessary if the histologic and immunohistochemical features are equivocal. ${ }^{23}$

There have also been some studies done, further detailing the genomic features of EBV +DLBCL and other lymphomas using next generation sequencing, gene expression profiling and other molecular methods. It may be useful in the future, once these technologies are more widely available. ${ }^{24,25}$ 
The prognosis and appropriate treatment of EBV+ DLBCL is markedly different between these closely related entities. ${ }^{2,26}$ EBV positivity is associated with more advanced stage, extranodal involvement, and poorer response to treatment. ${ }^{2,4}$

Although lymphomas in general are chemosensitive, the exact chemotherapeutic regimen to be used will differ according to the specific type. HL generally involves adjacent nodes in the same anatomic site, and typically spreads to adjacent nodal areas; isolated deposits in distant nodes is rare. $^{27}$ Combination chemotherapy consisting of doxorubicin, vinblastine, bleomycin, and dacarbazine (ABVD) is typically given, and a scoring system is currently in use to determine patient's prognosis. $^{28}$ The International Prognostic Score (IPS) is the most commonly used risk stratification system for this disease, and is highly predictive of freedom from disease progression. ${ }^{29}$ This includes clinical and laboratory parameters such as gender, serum albumin, hemoglobin, stage, age, white blood cell count, and lymphocyte count. ${ }^{29}$ Initial treatment with chemotherapy, with or without radiotherapy, generally results in cure.

Gray zone lymphoma is a rare neoplasm that has a more aggressive course with poorer outcomes. ${ }^{30}$ This typically presents in males, and is more often diagnosed at an advanced stage. ${ }^{30}$ There are currently no standard management guidelines for gray zone lymphoma. However, a prospective study has found that these patients typically respond to a combination regimen consisting of dose-adjusted etoposide, doxorubicin, and cyclophosphamide with vincristine, prednisone, and rituximab (DA-EPOCH-R), with $62 \%$ of patients achieving continuous complete remission. ${ }^{31}$

Patients with NHL typically present with painless peripheral lymphadenopathy. This may or may not be accompanied by B symptoms. DLBCL is the most common histologic subtype of NHL, accounting for around $31 \%$ of this disease. Prognosis for this disease depends on histology and clinical parameters rather than stage, and a scoring system is currently being used to determine prognosis. The International Prognostic Index (IPI) identified age, serum LDH, performance status, stage, and extranodal involvement to be predictive of survival. ${ }^{32}$ Combination therapy with cyclophosphamide, doxorubicin, vincristine, and prednisone, with or without rituximab (R-CHOP), is the first-line treatment. ${ }^{33}$ The treatment strategies of $\mathrm{EBV}+$ DLBCL currently follow that of other DLBCL, however, clinical trials involving activation of lytic viral genes that will render tumor cells susceptible to antiviral treatment are currently being studied. Other therapeutic methods under study include boosting the anti-viral immune response with vaccines or EBV-specific cytotoxic lymphocytes. ${ }^{34}$

Although the previously discussed entities involve lymphohematopoietic tissues, their biologic and clinical behaviors are distinct. It is therefore imperative that an accurate histopathologic diagnosis is made in order to determine the correct treatment strategy for these patients.

\section{CONCLUSION}

EBV + DLBCL should be considered as a differential diagnosis in immunocompetent patients presenting with rapidly enlarging extranodal masses and multiple lymphadenopathies, especially if histologic examination of the mass reveals RS-like cells in a reactive background. It is also important to perform immunohistochemical studies and EBER-ish to attain a specific diagnosis. It is recommended that clinicians and pathologists test for and report EBV positivity in cases of lymphoma as this affects prognosis and treatment.

\section{ACKNOWLEDGMENTS}

The authors would like to thank Dr. Irma Veroy and Dr. Krisha Castro for their assistance in procuring the radiologic images of this case.

\section{ETHICAL CONSIDERATION}

Patient consent was obtained before submission of the manuscript.

\section{STATEMENT OF AUTHORSHIP}

All authors certified fulfillment of ICMJE authorship criteria.

\section{AUTHOR DISCLOSURE}

All authors declared no conflict of interest.

\section{FUNDING SOURCE}

None.

\section{REFERENCES}

1. Smith A, Howell D, Patmore R, Jack A, Roman E. Incidence of haematological malignancy by sub-type: a report from the Haematological Malignancy Research Network. Br J Cancer. 2011 Nov;105(11):1684-92. PMID: 22045184. PMCID: PMC3242607. https://doi. org/10.1038/bjc.2011.450.

2. Swerdlow SH, Campo E, Harris NL, et al., eds. WHO Classification of tumors of hematopoietic and lymphoid tissues, revised 4th ed, vol. 2. IARC: Lyon; 2017.

3. Oyama T, Ichimura K, Suzuki R, et al. Senile $\mathrm{EBV}+\mathrm{B}$-cell lymphoproliferative disorders: a clinicopathologic study of 22 patients. Am J Surg Pathol. 2003;27(1):16-26. PMID: 12502924. https:// doi.org/10.1097/00000478-200301000-00003.

4. Castillo JJ, Beltran BE, Miranda RN, Young KH, Chavez JC, Sotomayor EM. EBV-positive diffuse large B-cell lymphoma, not otherwise specified: 2018 update on diagnosis, risk-stratification and management. Am J Hematol. 2018;93(7):953-62. PMID: 29984868. https://doi.org/10.1002/ajh.25112.

5. Sato A, Nakamura N, Kojima M, et al. Clinical outcome of Epstein-Barr virus-positive diffuse large B-cell lymphoma of the elderly in the rituximab era. Cancer 
Sci. 2014;105(9):1170-5. PMID: 24974976. PMCID: PMC4462402. https://doi.org/10.1111/cas.12467.

6. Lu TX, Liang JH, Miao Y, et al. Epstein-Barr virus positive diffuse large B-cell lymphoma predict poor outcome, regardless of the age. Sci Rep. 2015;5:12168. PMID: 26202875. PMCID: PMC4511873. https://doi. org/10.1038/srep12168.

7. Hong JY, Yoon DH, Suh C, et al. EBV-positive diffuse large B-cell lymphoma in young adults: is this a distinct disease entity? Ann Oncol. 2015;26(3):548-55. PMID: 25475080. https://doi.org/10.1093/annonc/mdu556.

8. Hoeller S, Tzankov A, Pileri SA, Went P, Dirnhofer S. Epstein-Barr virus-positive diffuse large B-cell lymphoma in elderly patients is rare in Western populations. Hum Pathol. 2010;41(3):352-7. PMID: 19913281. https://doi.org/10.1016/j.humpath.2009. 07.024 .

9. Hofscheier A, Ponciano A, Bonzheim I, et al. Geographic variation in the prevalence of EpsteinBarr virus-positive diffuse large B-cell lymphoma of the elderly: a comparative analysis of a Mexican and a German population. Mod Pathol. 2011;24(8): 1046-54. PMID: 21499229. https://doi.org/10.1038/ modpathol.2011.62.

10. Laurini JA, Perry AM, Boilesen E, et al. Classification of non-Hodgkin lymphoma in Central and South America: a review of 1028 cases. Blood. 2012;120(24):4795-801. PMID: 23086753. https://doi. org/10.1182/blood-2012-07-440073

11. Gibson S, Hsi E. Epstein-Barr virus-positive B-cell lymphoma of the elderly at a United States tertiary medical center: an uncommon aggressive lymphoma with a nongerminal center B-cell phenotype. Hum Pathol. 2009;40(5):653-61. PMID: 19144386. https:// doi.org/10.1016/j.humpath.2008.10.007.

12. Yap MG, Tiangco B. Clinicopathologic profile of Filipino patients with malignant lymphomas. Philipp J Intern Med. 2014;42(6):289-96. https://www.herdin. $\mathrm{ph} /$ index.php/component/herdin/?view $=$ research\&c $\mathrm{id}=36236$. Accessed March 8, 2021.

13. Paulino AF, Medeiros LJ, Paulino-Cabrera E, Weiss LM. Hodgkins disease in the Philippines. Mod Pathol. 1996. https://www.herdin.ph/index.php/component/ herdin/?view $=$ research\&cid $=28735$. Accessed March 8, 2021.

14. Nicolae A, Pittaluga S, Abdullah S, et al. EBVpositive large B-cell lymphomas in young patients: a nodal lymphoma with evidence for a tolerogenic immune environment. Blood. 2015;126(7):863-72. PMID: 25999451. PMCID: PMC4536540. https:// doi.org/10.1182/blood-2015-02-630632.

15. Cohen M, Narbaitz M, Metrebian F, De Matteo E, Preciado MV, Chabay PA. Epstein-Barr viruspositive diffuse large B-cell lymphoma association is not only restricted to elderly patients. Int J Cancer. 2014;135(12):2816-24. PMID: 24789501. https://doi. org/10.1002/ijc.28942.

16. Beltran BE, Morales D, Quiñones P, Medeiros LJ, Miranda RN, Castillo JJ. EBV-positive diffuse large b-cell lymphoma in young immunocompetent individuals. Clin Lymphoma Myeloma Leuk. 2011;11(6):512-6. PMID: 21889434. https://doi.org/ 10.1016/j.clml.2011.07.003.
17. Medeiros LJ, Miranda RN. Diagnostic pathology: lymph nodes and extranodal lymphomas, 2nd ed. Second. Salt Lake City, UT: Elsevier; 2017.

18. Adam P, Bonzheim I, Fend F, Quintilla-Martinez L. Epstein-Barr virus-positive diffuse large B-cell lymphomas of the elderly. Adv Anat Pathol. 2011;18(5):349-55. PMID: 21841405. https://doi. org/10.1097/PAP.0b013e318229bf08.

19. Wang E, Papavassiliou P, Sebastian S. A malignant lymphoma with histological features and immunophenotypic profile intermediate between EBV-positive diffuse large B-cell lymphoma and EBV-positive classical Hodgkin lymphoma in a 67-year-old female: a "gray zone" lymphoma associated with Epstein-Barr virus in the elderly. Pathol Res Pract. PMID: 22572037. https://doi.org/10.1016/j.prp.2012.04.003.

20. Medeiros LJ, Ioachim HL. Ioachim's lymph node pathology. 4th ed. Philadelphia, PA: Wolters Kluwer Health; 2009.

21. Kanderi T, Khoory MS. Infectious mononucleosis mimicking Epstein-Barr virus positive diffuse large B-cell lymphoma not otherwise specified. Int J Hematol Oncol. 2020;9(2):IJH25. PMID: 33005328. PMCID: PMC7510517. https://doi.org/10.2217/ijh2020-0002.

22. Louissaint A, Ferry JA, Soupir CP, Hasserjian RP, Harris NL, Zukerberg LR. Infectious mononucleosis mimicking lymphoma: distinguishing morphological and immunophenotypic features. Mod Pathol. 25(8):1149-59. PMID: 22627742. https://doi.org/ 10.1038/modpathol.2012.70.

23. Ding Y, Zhang L (eds). Practical oncologic molecular pathology: frequently asked questions. 1st ed. Springer; 2021.

24. Zhou Y, Xu Z, Lin W, et al. Comprehensive genomic profiling of EBV-positive diffuse large B-cell lymphoma and the expression and clinicopathological correlations of some related genes. Front Oncol. 2019;9:683. PMID: 31403034. PMCID: PMC6669985. https://doi.org/10.3389/fonc.2019.00683.

25. Gebauer N, Künstner A, Ketzer J, et al. Genomic insights into the pathogenesis of Epstein-barr virusassociated diffuse large B-cell lymphoma by wholegenome and targeted amplicon sequencing. Blood Cancer J. 2021;11(5):102. PMID: 34039950. PMCID: PMC8155002. https://doi.org/10.1038/s41408-02100493-5.

26. Park S, Lee J, Ko YH, et al. The impact of EpsteinBarr virus status on clinical outcome in diffuse large B-cell lymphoma. Blood. 2007;110(3):972-8. PMID: 17400912. https://doi.org/10.1182/blood-2007-01067769 .

27. Rosenberg SA, Kaplan HS. Evidence for an orderly progression in the spread of hodgkin's disease. Cancer Res. 1966;26(6):1225-31. PMID: 5947346.

28. Hodgkin lymphoma. NCCN Clinical Practice Guidelines in Oncology. Ver 3.2021. https://www.nccn. org/professionals/physician_gls/pdf/hodgkins.pdf. Accessed March 7, 2021.

29. Hasenclaver D, Diehl V. A prognostic score for advanced Hodgkin's disease. International Prognostic Factors Project on Advanced Hodgkin's Disease. N Engl J Med. 1998;339(1):1506-14. PMID: 9819449. https://doi.org/10.1056/NEJM199811193392104. 
30. Pilichowska M, Kritharis A, Evens M. Gray zone lymphoma: current diagnosis and treatment options. Hematol Oncol Clin North Am. 2016;30(6):1251-60. PMID: 27888879. https://doi.org/10.1016/j.hoc.2016. 07.006 .

31. Wilson W, Pittaluga S, Nicolae A, et al. A prospective study of mediastinal gray zone lymphoma. Blood. 2014;124(10):1563-19. PMID: 25024303. PMCID: PMC4155269. https://doi.org/10.1182/blood-201403-564906.

32. International Non-Hodgkin's Lymphoma Prognostic Factors Project. A predictive model for aggressive non- Hodgkin's lymphoma. N Engl J Med. 1993; 329(14):987-94. PMID: 8141877. https://doi. org/10.1056/NEJM199309303291402.
33. B - cell lymphomas. NCCN Clinical Practice Guidelines in Oncology. Ver 3.2021. https://www.nccn.org/ professionals/physician_gls/pdf/b-cell.pdf. Accessed March 7, 2021.

34. Kanakry J, Ambinder R. EBV related lymphomas: new approaches to treatment. Curr Treat Options Oncol. 2013;14(2):224-36. PMID: 23549980. PMCID: PMC3670765. https://doi.org/10.1007/s1 1864-0130231-y.

Disclaimer: This journal is OPEN ACCESS, providing immediate access to its content on the principle that making research freely available to the public supports a greater global exchange of knowledge. As a requirement for submission to the PJP, all authors have accomplished an AUTHOR FORM, which declares that the ICMJE criteria for authorship have been met by each author listed, that the article represents original material, has not been published, accepted for publication in other journals, or concurrently submitted to other journals, and that all funding and conflicts of interest have been declared. Consent forms have been secured for the publication of information about patients or cases; otherwise, authors have declared that all means have been exhausted for securing consent.

\section{Publish in the new PJP. Visit our website: htp://philippinejournalofpathology.org}

